\title{
Magnitude of self-medication practice and the associated factors among adult household members living in western region, Tanzania
}

Mussa S. Manhyabili

Muhimbili University of Health and Allied Sciences

George M. Bwire ( $\nabla$ georgebwire@gmail.com )

Muhimbili University of Health and Allied Sciences

Lubinza Maziku

Muhimbili University of Health and Allied Sciences

Mecky .I. N. Matee

Muhimbili University of Health and Allied Sciences

\section{Research Article}

Keywords: self-medication, associated factors, adult households, Shinyanga, Tanzania

Posted Date: September 10th, 2021

DOl: https://doi.org/10.21203/rs.3.rs-879956/v1

License: (c) (i) This work is licensed under a Creative Commons Attribution 4.0 International License. Read Full License 


\section{Abstract}

Background: Self-medication practice (SMP) is the use of medication without the prescription of health care professionals. The major problems associated with self-medication practice have been drug resistance, drug side effects, wastage of resources, and serious health hazards including death. This study was conducted to assess the magnitude and factors associated with self-medication practice among adult household members in Shinyanga Municipal Council (SMC).

Methods: A community based cross-sectional study was conducted in SMC, in September and October 2020. A multistage cluster random sampling was used to select study participants. Variables such as socio-demographic factors and reasons for SMP were summarized using frequencies and percentages. Chi square and logistic regression test were used to identify factors associated with SMP. All statistics were done using SPSS version 25.

Results: In total 422 adult household members were studied, the magnitude of SMP among adult household members in SMC was $86 \%$. The major symptom of illness that lead to SMP were headache 75(38.9\%), fever 71 (37\%) and cough 52 (27.1\%) while paracetamol 84(43.8\%), Ampiclox 30 (15.5\%) and artemether lumefantrine 25 (13\%) were the commonly used drugs. Perceptions of illness as mild $141(38.8 \%)$ and previous experience of self-medication138(38\%) were the reasons for SMP. Participants who did not complete secondary education were seven times more likely to practice SMP as compared to those who had university education (adjusted odds ratio $[\mathrm{aOR}]=7.136,95 \% \mathrm{Cl}=1.447-35.180, \mathrm{P}=0.016$ ). Participants with average household income (AHI) $(<180,000 \mathrm{TSH}=<78 \mathrm{USD})$ were less likely to practice SMP compared to those with AHI (B 180,000Tsh) $(a O R=0.424,95 \% \mathrm{Cl}=0.214-0.840, \mathrm{P}=0.014)$.

Conclusion: The magnitude of SMP in Shinyanga Municipal was found to be high.SMP was significantly associated with level of education and average monthly household income. Strengthening of the community's awareness on the side effects of SMP including antimicrobial resistance in the study area is recommended.

\section{Background}

Self-medication practice (SMP) defined as any use of medications without the prescriptions of health care professionals for the treatment of self- recognized illnesses which occur frequently for various reasons $(1,2)$ Self-medication is highly practiced worldwide and high prevalence is in developing countries, the frequencies of self-medications practices vary from country to country and from one geographical location to the other. In Africa frequency of self-medication ranges from $11.9-75.7 \%$ (3).

Self-medication has been associated with previous experience of self-medication, and accessibility of pharmacy, peer/family pressure and presence of medication at home(1). Others includes perception of illness as mild, similarity of symptoms with previous illness, inability to afford health care fee and poor quality of health facility such as long queues and long distance to health facilities $(1,4)$. Additional reasons includes emergency illness, advertisement from television, radio and printed media(5). The most 
common reported drugs that are used for self-medication include antipyretics, analgesics, antibiotics, cough syrups, and antimalarial $(4,6)$. The symptoms that are reported to self-medication includes common cold, cough, fever, general pains, vomiting, diarrhea and skin conditions (4).

Several studies have cited the reasons for self-medication to include Community pharmacies, lack of money to consult a medical doctor, sex, education status and occupation of the respondent(4, 7-11). However, little was known of the situation in the Lake Zone areas of the country. Thus, the objective of the present study was to determine the self-medication practices and associated factors among adult household members in Shinyanga Municipal council. Self-medication practice influences health care seeking behavior of individuals. It leads to wastage of resources, delay in diagnosis of problems and appropriate treatments. Can also lead to serious health hazards, emergence of antibiotic resistant strains of micro-organisms and adverse drug reactions $(1,12)$.

Given high burden of infectious diseases in Tanzania, limited healthcare facilities and increased quantities of drug dispensing outlet resulting in increased use and accessibility of medicines by consumers, thereby giving options for its misuse. Thus; self-medication with either antibiotic or antimalarial is still a common practices in some part of Tanzania(13).

Despite the growing research interest on the topic from different parts in Tanzania, not much was known about self-medication practice in general population by people from Lake Zone. This study was focused on identifying self-medication practice and associated factors among adult household members in Shinyanga Municipal council.

\section{Methods}

\section{Study design, period and setting}

A descriptive community based cross-sectional was conduct between September to October2020.The study was conducted in Shinyanga Municipal Council found in Shinyanga Region, Lake Zone in Tanzania. It is bordered to the north by Mwanza region to South by Shinyanga Rural district, to East by Kishapu district and to the west by Kahama district. According to Tanzania Census of 2012, the district had 152098 inhabitants. Shinyanga Municipal has 11 healthcare facilities and Shinyanga Regional Referral Hospital (RRH).

\section{Study population}

All adults with age $\geq 18$ years old and resident of Shinyanga Municipal Council were recruited and given consent to participate in this study. A minimum sample size of 422 was estimate $d$ using a crosssectional formula; sample size $(n)=Z^{2} P(1-P) / d^{2}$ ( $Z=$ confidence level of $95 \%$ which is $1.96, P=$ estimated prevalence of $0.5, \mathrm{~d}=$ precision or margin of error allowed in this study degree of precision was 0.05 ), and plus $10 \%$ of non-response rate. Multistage cluster random sampling technique was used, first to select 5 
wards out of 13 wards. Then, 2 streets were selected from each selected Ward. Lastly, households were divided into clusters based on proximity and one household was picked randomly.

\section{Data collection}

A semi-structured questionnaire was developed following a comprehensive literature review $(4,7,9-12)$ to collect data from the study area. The questionnaire was included information about socio-demographic characteristics including age, sex, marital status, educational level, average income status number of members in household and occupation, Information on self-reported health aspects of respondents, such as their health status; respondent was asked about whether they had practiced self-medication (both prescription only and over the counter drugs) during the last one month before the day of interview. Other information included, drug groups used for self-medication, and symptoms/lllness and reasons for selfmedication. Data was collected in a face-to-face interview on a structured questionnaire.

\section{Data analysis}

Data collected were entered into statistical analysis software, Statistical Package for Social Science (SPSS) version 25 for analysis (Chicago Inc., USA).Descriptive statistics such as socio-demographic characteristics were summarized using frequencies and percentages. The magnitude of SMP was determined by dividing the number of participants who reported to practice SMP to the total number of participants enrolled in the study. The Chi-square and logistic regression test were used to determine factors associated with self-medication practice. A P value for significance was considered at $<0.05$.

\section{Ethical considerations}

Ethical approval to conduct this study was sought from Muhimbili University of Health and Allied Science Research and Publications Committee (Reference No. DA.25/111/01/). Furthermore, permissions to collect data were obtained from the respective local authorities. Confidentiality of participants' information was insured through the use of codes (numbers) during data collection, analysis, interpretation and presentation. Participants were enrolled after obtaining an informed verbal consent. This study was conducted accordance to the law and regulations of the United Republic of Tanzania.

\section{Results}

\section{Participants socio-demographic characteristics}

In total 422 participants were enrolled, most of the participants had age between 25-34 years $145(34.4 \%)$. More than half of participants were males 217 (51.4\%). The level of education and average monthly household income were significantly ( $p$ vale<0.05) associated with SM practices. Table 1$)$. 


\section{Magnitude, common symptoms and drugs used for self-medication}

The study revealed that the magnitude of self- medication among household adults at Shinyanga municipal were $363(86 \%)$ as results summarized. But among $363(85.6 \%)$ participants, $183(59.7 \%)$ participants use self-medication very rarely whereas $192(60.7 \%)$ participants used self- medication one month before or within the months of study conducted. The common symptoms of illness that lead to self-medication were headache 75(38.9\%), fever 71(37\%) and cough 52(27.1\%) (Figure 1a). The study revealed that paracetamol $84(43.8 \%)$, ampiclox 30(15.5\%) and artemether lumefantrine (ALU) 25(13\%) were the major drugs that used (Figure 1b).

\section{Reasons participants for self-medication practice}

Perceptions of illness as mild 141(38.8\%), previous experience of self-medication138 (38\%) and emergency illness $34(9.4 \%)$ were the major reasons for self-medication practice (Table 2 )

\section{Univariate and multivariate analysis on the factors associated with SM practice}

Participants who had not completed secondary school were about 7.136 fold more likely to practice selfmedication compared with those attained university education $(\mathrm{aOR}=7.136,95 \% \mathrm{Cl}=1.447-35.180, \mathrm{P}$ value $=0.016$ ). Also those completed primary school were 4.919 fold more likely to practice self-medication as compared to those university level $(\mathrm{aOR}=4.919,95 \% \mathrm{Cl}=1.515-15.973, \mathrm{P}$ value $=0.008)$. Participants with 180,000 Tshs average household monthly income were $57.6 \%$ self-medication practices as compared to those with 180,000 Tshs $(a O R=0.424,95 \% \mathrm{Cl}=0214-0840, \mathrm{P}$ value $=0.014)$ (Table 3).

\section{Discussion}

This study aimed to determine self-medication practices among adult household members living in Shinyanga Municipal Council, Tanzania. In this study, the magnitude of self-medication practice was found to be $86 \%$, a level which close to observations reported in Northern Uganda $75.7 \%$ (3), and Kenya $79 \%(14)$.The level of self-medication reported in this study, is higher than that reported in other Tanzania studies in Pwani Region 64.8\% (4), and Siha district in Kilimanjaro 58\%(15), and among pregnant women in Mwanza 46.24\% (10) and Mbeya 55.6\% (11). These variations could be due to difference in drug shops and pharmacy to obtain drugs for SMP. Area such as Pwani and Siha rural area such that in rural there is few (23-24). Also another reason could be participants enrolled during clinic visit/ admitted at health centre (10) or hospital (11) more likely to respond that had never SMP.

The common symptoms of illness that lead to self-medication included headache $38.9 \%$, fever $37 \%$, and cough $27.1 \%$, an observation that is comparable to several other studies in which headache and fever were the leading symptoms $(1,4,11,12,15)$.

We found out that the reasons for self-medication practices were perceptions of illness as being mild $38.8 \%$, history of previous experience of self-medication $38 \%$, emergency illness $9.4 \%$, peer/family pressure $7.7 \%$, presence of medication at home $7.2 \%$, long queues $5 \%$, long distance to health facilities 
$4.1 \%$, close proximity to pharmacy/drug shops $3.9 \%$, poor quality of health facilities $3.9 \%$ and inability to afford health care fee $3.6 \%$. This was similar to previous studies $(1,4,5,12,15,17)$.

This study showed that paracetamol $43.8 \%$, ampiclox $15.5 \%$ and ALU13\% were the most frequently used medications. In Tanzania aforementioned drugs can be available and accessed through Accredited Drug Dispensing Outlets (ADDO) Programme, even without a prescription (20-22).

The reported outcomes were majority of participants getting better after SM $86.2 \%$ and few of them not get better after SM $3.8 \%$ and the actions were visited health facility $70 \%$, nothing $20 \%$, repeated SM $8 \%$ and went to tradition healers $1(2 \%)$. The expiations for this could be due participants having sufficient knowledge about drug choice, dose and time of intake (25).

In this study, the results of multivariate logistic regression analysis showed that participants who had not completed secondary school and those completed primary school were more likely to practice selfmedication as compared to those university level. This results were similar to other studies $(4,10,26-$ 30 ). This is due to fact high education level is associated with promptness in seeking care from health care providers(31) and attendance to clinic (32).

Also, in this study, showed that low income household less likely to SMP compared to those had high income. This is due the fact that rich people more likely to opt to have freedom to purchase medications from private pharmacy/ drug shops as they can afford (33). This is contrary to most of the studies which showed no significant association of level of income to the $\operatorname{SMP}(1,4,5,10)$. This difference could be due to difference in socio-economic status of the participants.

\section{Study Limitations}

In this study, there were two potential study limitations. First, because information about SM was selfreported, one would anticipate the possibility of recall bias. The recall bias was minimized by minimizing the reporting window to be as short as one month before the survey. Second, some participants were not able to remember the names of medicines; they were requested to bring the container of drugs used and/ or leftover medications.

\section{Conclusion}

The magnitude of SMP in Shinyanga Municipal was found to be high.SMP was significantly associated with level of education and average monthly household income. Strengthening of the community's awareness in Shinyanga Municipal on the side effects of self-medication practice including antimicrobial resistance and regulation of pharmacies/drug shops are very important mechanisms to decrease the practice. Thus, integrated efforts of individuals, communities, health facilities, and the regulatory bodies are highly important.

\section{Declarations}




\section{Ethical approval and consent to participate}

Ethical approval to conduct this study was sought from Muhimbili University of Health and Allied Science Research and Publications Committee (Reference No. DA.25/111/01/). Furthermore, permissions to collect data were obtained from the respective local authorities. Confidentiality of participants' information was insured through the use of codes (numbers) during data collection, analysis, interpretation and presentation. Participants were enrolled after obtaining an informed verbal consent. This study was conducted accordance to the law and regulations of the United Republic of Tanzania.

\section{Authors' contributions}

MSM participated in conception, research design, data collection, data analysis and interpretation and drafting of the manuscript. MINM participated in research design, data analysis, data interpretation and revising the manuscript. GMB and LM participated in data analysis and revising the manuscript. All authors read and approved the final version of this manuscript.

\section{Competing interests}

Authors declare that there is no competing interest

\section{Consent to publish}

Not applicable

\section{Availability of data and materials}

All relevant data generated and analysed during this study are available fromthe corresponding author on reasonable request

\section{Funding}

This study was carried out as part of our routine work.

\section{Acknowledgements}

Authors thanks the participants who participated in this study. We also thank the local authorities for granting permission to conduct this study.

\section{Authors' information}

${ }^{1}$ Department of Microbiology and Immunology, School of Medicine, Muhimbili University of Health and Allied Sciences, P.O.Box 65001, Dar es Salaam, Tanzania. ${ }^{2}$ Department of Pharmaceutical Microbiology, School of Pharmacy, Muhimbili University of Health and Allied Sciences, P.O.Box 65001, Dar es Salaam, Tanzania 


\section{References}

1. .Kassie AD, Bifftu BB, Mekonnen HS. Self-medication practice and associated factors among adult household members in Meket district, Northeast Ethiopia, 2017. BMC Pharmacology and Toxicology (2018) 19:15 https://doi.org/10.1186/s40360-018-0205-6.

2. Gupta P, Bobhate PS, Shrivastava SR. Determinants of self-medication practice in an urban slum community. Asian J Pharm Clin Res, Vol 4, Issue 3, 2011, 5457.

3. Ocan M, Bwanga F, Bbosa GS, Bagenda D, Waako P, Ogwal- J, et al. Patterns and Predictors of SelfMedication in Northern Uganda. PLOS ONE | 2014 | Volume 9 | Issue 3 | e92323.www.plosone.org.

4. Kazaura MR. Level and Correlates of Self-medication among Adults in a Rural Setting of Mainland Tanzania.. Indian J Pharm Sci 2017; 79(3):451-457.

5. Kajeguka DC, Moses EA. Self-medication practices and predictors for self-medication with antibiotics and antimalarials among community in Mbeya City. Tanzania Journal of Health Research Volume 19, Number 4, October 2017: http://dx.doi.org/10.4314/thrb.v19i4.6

6. Ahmed NM. Self-Medication Practice among Patients Attending a sample of Primary Health Care Centers in Erbil City. 2016;7(24):73-79.

7. Access 0 . Irrational use of antibiotics in the Moshi Municipality Northern Tanzania: a cross sectional study. 2018;8688:1-10.

8. Lusinge Misperception, practice and risk factors for self-medication among residents of Kakonko district, 2017.Retrived from www.semanticscholar.org.

9. Marealle Al, Kirutu P.Self-medication with antu-malarial medicines among high school students in Dar es salaam,Tanzania 2018;10(8):19-21

10. Marwa KJ, Njalika A, Ruganuza D, Katabalo D, Kamugisha E. Self-medication among pregnant women attending antenatal clinic at Makongoro health centre in Mwanza, Tanzania : a challenge to health systems. BMC Pregnancy and Childbirth (2018) 18:16.

11. Mwabamba G. Prevalence and Knowledge of Self-Medication: A Cross- Sectional Study in Mbeya Urban, Southwestern Tanzania. 2017;2(1):1-5.

12. Abrha S, Molla F, Melkam W. Self-medication Practice: the Case of Kolladiba Town, North West Ethiopia. 2014;5(10):670-7.

13. Chipwaza B, Mugasa JP, Mayumana I, Amuri M, Makungu C, Gwakisa PS. Self-medication with antimalarials is a common practice in rural communities of Kilosa district in Tanzania despite the reported decline of malaria. 2014;13(1):1-11.

14. Res IJA, Mukaka VE, Kosgey SJ, Isiaho LA..Knowledge on the effects of self-medication among community member in Nandi.. 2018;6(11):23-31.

15. Kumburu HH, Sonda TB, Mwanziva CE, Mshana E, Mmbaga BT, Kajeguka DC, et al. Prevalence, determinants and knowledge of antibacterial self-medication : A cross sectional study in Northeastern Tanzania. 2018;1-13. 
16. Mamo S, Ayele Y, Dechasa M. Self-Medication Practices among Community of Harar City and Its Surroundings, Eastern Ethiopia. 2018;2018.

17. Sambakunsi CS, Småbrekke L, Varga CA, Solomon V, Mponda JS. Knowledge, attitudes and practices related to self- medication with antimicrobials in Lilongwe, Malawi. 2019;31(December):225-32.

18. Ocan M, Bbosa GS, Waako P, Ogwal-okeng J, Obua C. Factors predicting home storage of medicines in Northern Uganda. 2014;1-7.

19. Araia ZZ, Gebregziabher NK, Mesfun AB. Self medication practice and associated factors among students of Asmara College of Health Sciences, Eritrea : a cross sectional study. 2019;2:1-9.

20. Centre for Pharmaceutical Management. Accredited Drug Dispensing Outlets in Tanzania: Strategies for Enhancing Access to Medicines Program. Management Sciences for Health. 2008. .

21. Chalker JC, Vialle-Valentin C, Liana J, Mbwasi R, Semali IA, Kihiyo B, et al. What roles do accredited drug dispensing outlets in Tanzania play in facilitating access to antimicrobials? Results of a multimethod analysis. Antimicrob Resist Infect Control. 2015; 4: 33. https://doi.org/10.1186/s13756015-0075-2 PMID: 2630108.

22. Valimba R, Liana J, Joshi MP, Rutta E, Embrey M, Bundala M, et al. Engaging the private sector to improve antimicrobial use in the community: experience from accredited drug dispensing outlets in Tanzania. J Pharm Policy Pract. 2014; 7: 11. https://doi.org/10.1186/2052-3211-7-11 PMID: 25298887.

23. Rutta $E$, et al. Accrediting retail drug shops to strengthen Tanzania's public health system: an ADDO case study. Journal of Pharmaceutical Policy and Practice 2015:1-15.

24. Supply M. Making Pharmaceutical market work for the poor. A case study in Tanzania.2010:1-10. globalfinancingfacility.org

25. Chouhan K, Prasad S. Self-medication and their consequences: A challenge to health professional.2016;9(2):314-317.

26. Awad A, Eltayeb I, Matowe L, Thalib L. Self-medication with antibiotics and antimalarials in the community of Khartoum state, Sudan. J Pharm Pharm Sci. 2005;8(2):326-31.

27. Afolabi A. Factors influencing the pattern of self-medication in an adult Nigerian population. Annals of African medicine. 2009;7(3):120-7.

28. Abosede O. Self-medication: an important aspect of primary health care. Soc Sci Med. 1984;19(7):699-703.

29. Balbuena FR, Aranda AB, Figueras A. Self-medication in older urban mexicans. Drugs Aging. 2009;26(1):51-60.

30. Biritwum R, Welbeck J, Barnish G. Incidence and management of malaria in two communities of different socio-economic level, in Accra, Ghana. Ann Trop Med Parasitol. 2000;94(8):771-8.

31. Tarimo DS, Lwihula GK, Minjas JN, Bygbjerg I. Mothers' perceptions and knowledge on childhood malaria in the holendemic Kibaha district, Tanzania: implications for malaria control and the IMCI 
strategy. Tropical Med Int Health. 2000;5(3):179-84.

32. Slutsker L, Chitsulo L, Macheso A, Steketee R. Treatment of malaria fever episodes among children in Malawi: results of a KAP survey. Tropical medicine and parasitology: official organ of Deutsche Tropenmedizinische Gesellschaft and of Deutsche Gesellschaft fur Technische Zusammenarbeit (GTZ). 1994;45(1):61-4.

33. Macha et al. Determinants of community health fund membership in Tanzania: a mixed methods analysis. BMC Health Services Research 2014, 14:538. http://www.biomedcentral.com/1472$6963 / 14 / 538$.

\section{Tables}

Table 1. Association between soci0demographic factors and the factors associated with SMP 


\begin{tabular}{|c|c|c|c|c|}
\hline \multirow[t]{3}{*}{ Variables } & \multirow[t]{3}{*}{ Category } & \multicolumn{2}{|c|}{ Self-medication practice } & \multirow{3}{*}{$\begin{array}{l}P \\
\text { value }\end{array}$} \\
\hline & & Yes & No & \\
\hline & & $\mathrm{n}(\%)$ & $\mathrm{n}(\%)$ & \\
\hline \multirow[t]{2}{*}{ Sex } & Male & $187(86.2 \%)$ & $30(13.6 \%)$ & \\
\hline & Female & $176(85.9 \%)$ & $29(14.1 \%)$ & 0.924 \\
\hline \multirow[t]{5}{*}{ Age in year } & $18-24$ & $94(83.9 \%)$ & $18(16.1 \%$ & \multirow{5}{*}{0.595} \\
\hline & $25-34$ & $126(86.9 \%)$ & $19(13.1 \%)$ & \\
\hline & $35-44$ & $60(88.2 \%)$ & $8(11.8 \%)$ & \\
\hline & $45-54$ & 49(81.7\%) & $11(18.3 \%)$ & \\
\hline & $\geq 55$ & $34(91.9 \%)$ & $3(8.1 \%)$ & \\
\hline \multirow[t]{5}{*}{ Marital status } & Single & $125(80.6 \%)$ & $30(19.4 \%)$ & \multirow{5}{*}{0.096} \\
\hline & Married & $218(89.3 \%)$ & $26(10.7 \%)$ & \\
\hline & Divorced & $6(100.0 \%)$ & $0(0.0 \%)$ & \\
\hline & Widowed & $12(85.7 \%)$ & $2(14.3 \%)$ & \\
\hline & Cohabiting & $2(66.7 \%)$ & $1(33.3 \%)$ & \\
\hline \multirow[t]{8}{*}{ Level of education } & Not attended & $24(85.7 \%)$ & $4(14.3 \%)$ & \multirow{8}{*}{0.004} \\
\hline & Not completed primary & $13(100.0 \%)$ & $0(0.0 \%)$ & \\
\hline & Completed primary & $93(93.9 \%)$ & $6(6.1 \%)$ & \\
\hline & Not completed & $45(95.7 \%)$ & $2(4.3 \%)$ & \\
\hline & 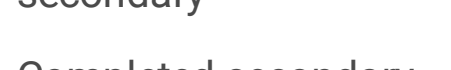 & 70(83.3\%) & $14(16.7 \%)$ & \\
\hline & evileter securitany & $53(77.9 \%)$ & $15(22.1 \%)$ & \\
\hline & voliage & $65(78.3 \%)$ & $18(21.7 \%)$ & \\
\hline & University & & & \\
\hline \multirow[t]{7}{*}{ Occupation } & Housewife & $51(89.5 \%)$ & $6(10.5 \%)$ & \multirow{7}{*}{0.066} \\
\hline & Businessman/woman & 73(86.9\%) & $11(13.1 \%)$ & \\
\hline & Farmer & $78(94.0 \%)$ & $\left.59^{\wedge} .0 \%\right)$ & \\
\hline & Casual laborer & $31(86.1 \%)$ & $5(13.9 \%)$ & \\
\hline & Employed & $58(82.9 \%)$ & 12(17.1\%) & \\
\hline & Unemployed & 49(81.7\%) & 11(18.3\%) & \\
\hline & Others* & $23(71.9 \%)$ & $9(28.1 \%)$ & \\
\hline
\end{tabular}


Average monthly household income

$$
\begin{aligned}
& <180,000 \text { Tsh } \\
& \geq 180,000 \text { Tsh }
\end{aligned}
$$

173(82.0\%) $\quad 38(18.0 \%)$

$190(90.0 \%) \quad 21(10.0 \%) \quad 0.017$

\begin{tabular}{|c|c|c|c|}
\hline Variable & Category & Frequency & Percent \\
\hline \multirow[t]{2}{*}{ Previous experience of self-medication } & Yes & 138 & 38 \\
\hline & No & 225 & 62 \\
\hline \multirow[t]{2}{*}{ Presence of medication at home } & Yes & 26 & 7.2 \\
\hline & No & 337 & 92.8 \\
\hline \multirow[t]{2}{*}{ Perception of illness as mild } & Yes & 141 & 38.8 \\
\hline & No & 222 & 61.2 \\
\hline \multirow[t]{2}{*}{ Peer/family pressure } & Yes & 28 & 7.7 \\
\hline & No & 335 & 92.3 \\
\hline \multirow[t]{2}{*}{ Close proximity to pharmacy/drug shop } & Yes & 14 & 3.9 \\
\hline & NO & 349 & 96.1 \\
\hline \multirow[t]{2}{*}{ Inability to afford health care fee } & Yes & 13 & 3.6 \\
\hline & No & 350 & 96.4 \\
\hline \multirow[t]{2}{*}{ Poor quality of health care facilities } & Yes & 14 & 3.9 \\
\hline & No & 347 & 96.1 \\
\hline \multirow[t]{2}{*}{ Long queues } & Yes & 18 & 5 \\
\hline & No & 345 & 95 \\
\hline \multirow[t]{2}{*}{ Long distance to health care facilities } & Yes & 15 & 4.1 \\
\hline & No & 348 & 95.9 \\
\hline \multirow[t]{2}{*}{ Emergency illness } & Yes & 34 & 9.4 \\
\hline & No & 329 & 90.6 \\
\hline
\end{tabular}

Table 2. Reasons that lead to self-medication

Table 3. Univariate and multivariate analysis on the factors associated with SM practice. 


\begin{tabular}{|c|c|c|c|c|c|c|c|}
\hline \multirow[b]{2}{*}{ Variable } & \multirow[b]{2}{*}{ Categories } & \multicolumn{3}{|c|}{ Univariate analysis } & \multicolumn{3}{|c|}{ Multivariate analysis } \\
\hline & & COR & $95 \% \mathrm{Cl}$ & $\begin{array}{l}P \\
\text { value }\end{array}$ & aCR & $95 \% \mathrm{Cl}$ & $\begin{array}{l}P \\
\text { value }\end{array}$ \\
\hline \multirow[t]{6}{*}{ Age (years) } & $18-24$ & 0.461 & \multirow{2}{*}{$\begin{array}{l}0.128- \\
1.663\end{array}$} & 0.237 & 0.949 & \multirow{2}{*}{$\begin{array}{l}0.175- \\
5.161\end{array}$} & 0.952 \\
\hline & $24-34$ & 0.585 & & 0.410 & 1.008 & & 0.992 \\
\hline & $35-44$ & 0.662 & $\begin{array}{l}0.163- \\
2.094\end{array}$ & 0.561 & 0.666 & $\begin{array}{l}0.205- \\
4.947\end{array}$ & 0.617 \\
\hline & $45-54$ & 0.393 & \multirow{2}{*}{$\begin{array}{l}0.164- \\
2.662\end{array}$} & \multirow[t]{2}{*}{0.175} & \multirow[t]{2}{*}{0.369} & \multirow{2}{*}{$\begin{array}{l}0.136- \\
3.269\end{array}$} & \multirow[t]{2}{*}{0.197} \\
\hline & \multirow{2}{*}{55} & \multirow{2}{*}{ Ref } & & & & & \\
\hline & & & $\begin{array}{l}0.102- \\
1.515\end{array}$ & & & $\begin{array}{l}0.081- \\
1.679\end{array}$ & \\
\hline \multirow[t]{2}{*}{ Sex } & Male & 1.027 & \multirow{2}{*}{$\begin{array}{l}0.592- \\
1.781\end{array}$} & \multirow[t]{2}{*}{0.924} & \multirow[t]{2}{*}{1.019} & \multirow{2}{*}{$\begin{array}{l}0.432- \\
2.404\end{array}$} & \multirow[t]{2}{*}{0.965} \\
\hline & Female & Ref & & & & & \\
\hline \multirow[t]{4}{*}{ Marital status } & Single & 2.083 & \multirow{2}{*}{$\begin{array}{l}0.183- \\
23.743\end{array}$} & 0.554 & 3.353 & \multirow{2}{*}{$\begin{array}{l}0.143- \\
78.872\end{array}$} & 0.453 \\
\hline & Married & 4.192 & & 0.249 & 6.229 & & 0.256 \\
\hline & Widowed & 3.000 & $\begin{array}{l}0,367- \\
47.842\end{array}$ & 0.447 & 6.212 & $\begin{array}{l}0.265- \\
146.29\end{array}$ & 0.325 \\
\hline & Cohabiting & Ref & $\begin{array}{l}0,177- \\
50.784\end{array}$ & & & $\begin{array}{l}0.163- \\
238.31\end{array}$ & \\
\hline \multirow{7}{*}{$\begin{array}{l}\text { Level of } \\
\text { education }\end{array}$} & Not attended & 1.662 & \multirow{2}{*}{$\begin{array}{l}0.510- \\
5.409\end{array}$} & 0.399 & 1.808 & \multirow{2}{*}{$\begin{array}{l}0.383- \\
8.550\end{array}$} & 0.455 \\
\hline & Completed primary & 4.282 & & 0.003 & 4.919 & & 0.008 \\
\hline & Not completed & 6.231 & 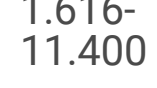 & 0.018 & 7.136 & $\begin{array}{l}1.515- \\
15.973\end{array}$ & 0.016 \\
\hline & $c^{2}$ & 1.385 & $1.377-$ & 0.411 & 1.837 & $1.447-$ & 0.180 \\
\hline & Collomas & 0.978 & & 0.956 & 1.160 & & 0.733 \\
\hline & colitage & Ref & 3.008 & & & 4.463 & \\
\hline & encose & & $\begin{array}{l}0.451- \\
2.124\end{array}$ & & & $\begin{array}{l}0.495- \\
2.718\end{array}$ & \\
\hline Occupation & Housewife & 3.326 & $\begin{array}{l}1.059- \\
10445\end{array}$ & 0.040 & 1.358 & $\begin{array}{l}0.303- \\
6085\end{array}$ & 0.689 \\
\hline & Businessman/woman & 2.597 & & 0.061 & 1.606 & & 0.440 \\
\hline & Farmer & 6.104 & 7.0444 & 0.003 & 3.166 & 5.346 & 0.112 \\
\hline & Casual laborer & 2.426 & $\begin{array}{l}1.861- \\
20026\end{array}$ & 0.154 & 1.783 & $\begin{array}{l}0.765- \\
13110\end{array}$ & 0.400 \\
\hline & Employed & 1.891 & & 0.207 & 1.967 & & 0.284 \\
\hline & Unemployed & 1.743 & 8.210 & 0.281 & 2.174 & 6.850 & 0.168 \\
\hline & Students & Ref & $\begin{array}{l}0.703- \\
5.090\end{array}$ & & & $\begin{array}{l}0.571- \\
6.783\end{array}$ & \\
\hline
\end{tabular}




\begin{tabular}{|c|c|c|c|c|c|c|c|}
\hline & & & $\begin{array}{l}0.634- \\
4.789\end{array}$ & & & $\begin{array}{l}0.720- \\
6.562\end{array}$ & \\
\hline Average & $<180,000$ Tsh & 0.503 & $0.284-$ & 0.018 & 0.424 & $0.214-$ & 0.014 \\
\hline income & $>180,000$ Tsh & Ref & & & & & \\
\hline Number of & $<5$ & 0.969 & $0.549-$ & 0.915 & 1.358 & $0.700-$ & 0.365 \\
\hline & $\geq 5$ & Ref & & & & & \\
\hline Position in the & Father & 2.058 & & 0.110 & 1.058 & $0.247-$ & 0.940 \\
\hline & Mother & 1.677 & & 0.220 & 0.825 & & 0.812 \\
\hline & Child & 0.910 & & 0.822 & 0.865 & 4.018 & 0.762 \\
\hline & Relative & Ref & & & & $\begin{array}{l}0.340- \\
2.203\end{array}$ & \\
\hline $\begin{array}{l}\text { Ref: reference cat } \\
\text { adjusted odds rat }\end{array}$ & y predicted t & of $s$ & nedica & $\begin{array}{l}\text { cOR: } \\
\text { old }\end{array}$ & de od & tio, a & \\
\hline
\end{tabular}

\section{Figures}

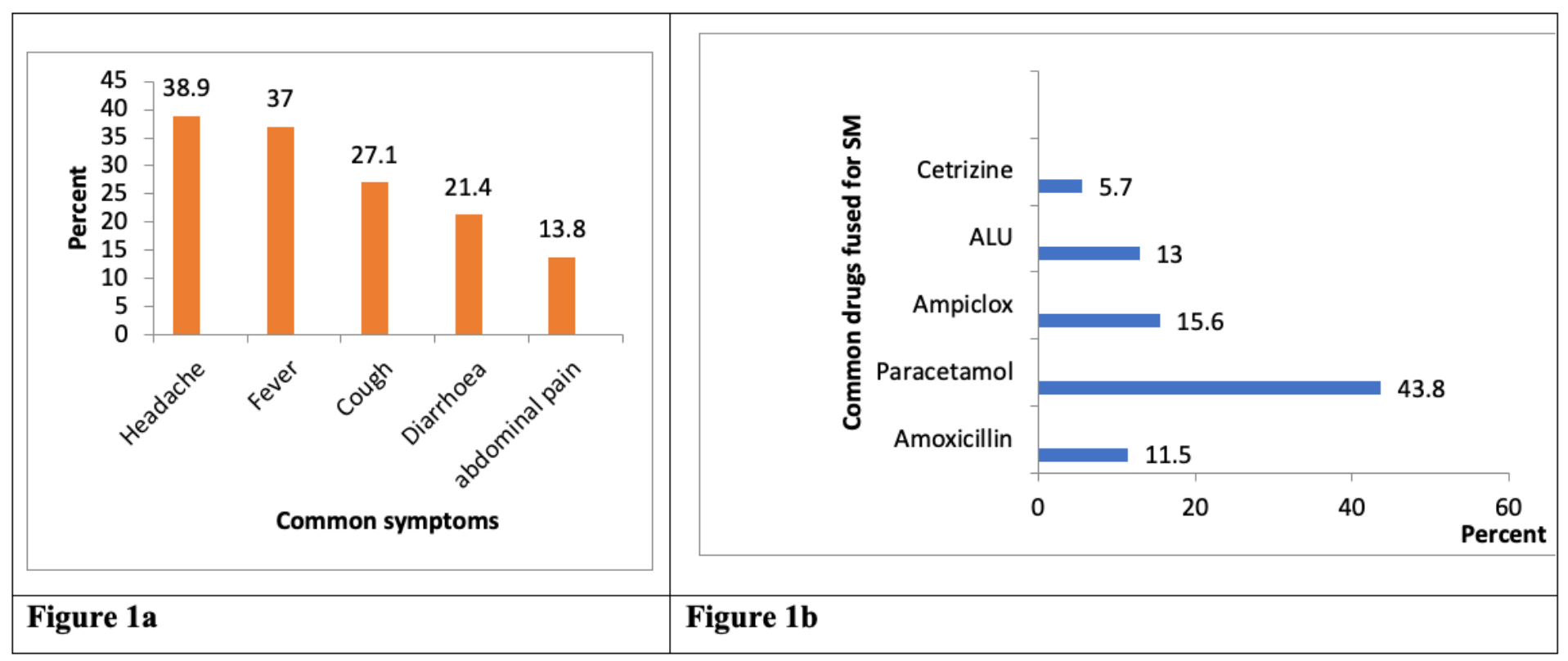

Figure 1

Common symptoms of illness (Figure 1a) and drugs (Figure 1b) used for SMP 